\title{
The Change of Religion and the Names
}

\author{
By John Kousgård Sørensen
}

What actually happened at the time when Denmark was christianized? How did Harald Bluetooth set about converting the Danes - the feat for which the large Jelling-stone gives him the credit? Was it a peaceful and gradual transition or the result of coercion, costing both blood and tears?

The earliest historical accounts concentrate, as was perhaps to be expected, on the dramatic events. In Denmark, the story of Svend Forkbeard's apostasy, his revolt against his Christian father, Harald Bluetooth, and his persecution of the Christians; in Sweden, the destruction of the temple at Uppsala by Olof Skötkonung; in Norway, the controversies that raged between Olav Tryggvason and St Olav and their fellow-countrymen in the period of Christianization.

As Birgit Sawyer has pointed out in the most recent survey of the old conversion histories (Sawyer 1987, $88 \mathrm{ff}$.), these old historians were propagandists. Their effective stories were designed at the time of composition to serve quite specific political ends, ends which were not always in harmony with the objective truth, and their accounts were never supposed to present a true picture of the events in the way that we would understand them today. Whatever the "historical" value of these stories, however, they are also evidence of tensions arising from the introduction of a new religion.

What was it like to live through this time of upheaval as an ordinary anonymous individual, a viking, a farmer, a slave or one of their women? What did they feel about the mission in their innermost souls and how did they experience it in their daily lives? It is only occasionally and as if by chance that the sources allow us to catch a glimpse of their situation. That we even dare venture to discuss this matter is only because we have been able to exploit indirect evidence. Since this evidence has first had to be interpreted, however, our results need to be treated with caution.

I should like to focus on the nomenclature, both personal names and place-names. What happened to these in the missionary period? Can they be exploited as evidence about the change of religion?

Let us begin with the personal names. What happened to these 
and to the naming practices in connection with the introduction of Christianity? This is one field of study which has not been exploited in this context in the present century. The question is relevant, however, because several pre-Christian cultic words entered into the personal nomenclature which the Christian mission found in use on its arrival.

It must be emphasized, however, that nobody was simply called by the name of a heathen god in Denmark. There was nobody called Tor or Odin or Frøa (Kousgård Sørensen 1974, 110). On the other hand, several names of gods, first and foremost Tor, occurred as one element of compound personal names: Torkil, Torsten, Tormod, Torgun. Similarly the words gud and as, referring to heathen gods, were also frequently employed as the first element of personal names: Gudmund, Gudrun, Aslak, Astrid, while a word such as vi 'sacred place' also occurred as an element in forenames: Vigøt, Visti, Vibjørg.

Were these heathen elements eradicated at one fell swoop, and the persons given new names, or were the potentially offensive elements gradually weeded out of the nomenclature? The answer to both of these questions is obvious, from the simple fact that almost all the names I have quoted are still in use today. Cultic elements were apparently not banished from the nomenclature in the Christian period.

It might be thought that the practice of bearing double-names, which has been noted both in the royal family and in the monastic orders in the first centuries of Christianity, is to be interpreted as an expression of the conflict between the old religion and the new one. Svend Forkbeard, for example, was also known as Otto after his christening, Svend Estridsen also as. Magnus, his mother Estrid also as Margarete and his daughter Gunhild also as Helena, to quote instances from the royal family alone. If these name-pairs are considered from an etymological point of view, however, it will be seen that there is only one of the pairs, Estrid-Margarete, in which a Scandinavian name with a cultic element (as) is opposed to a Christian name (the name borne by, among others, a third-century saint). These name-pairs cannot, then, be treated as indicators of religious differences. They are to be explained in a different way.

Christianity did not, then, attempt to eradicate heathen reminiscences from personal names. Why not? One answer might be that the mission had no particular desire to do this. There were other fields of action upon which it was more important for the mission to expend its resources than on the nomenclature.

Another answer would be that the cultic elements in the Scandinavian personal names were not recognised as such. It is not particularly 
likely that an element such as Es-, as in the above-mentioned Estrid or in the name of Archbishop Eskil, would be associated with the Scandinavian word for a god, as. Nor is it likely that the personal name Inge and the many names containing this name as an element would be understood to refer to heathen gods. The many short forms of names in Tor-, e.g. Toki, Tobbe, Tora, are also unlikely to have been associated with the god Tor in the minds of people living in the missionary period.

Some other names, such as the many names in Gud-, e.g. Gudmund, could without difficulty be associated with Christian concepts and thus would not give any cause for offence.

It is in any case very doubtful whether any eleventh- or twelfthcentury parents called their children Torgun or Asmund as a form of heathen provocation. There were other principles behind this choice of name (e.g. naming after ancestors, name-variation) and, as far as we can see, no objections were raised by the church to the continuation of the old practices. One of the earliest Danish bishops was called Odinkar, a name which can be assumed to have called up associations with darkest heathenism (even though this association is without etymological justification, for the first element is not the name of the god, cf. Kousgaird Sørensen 1974), but the name does not seem to have been at all offensive either to the bishop himself or to his Christian environment.

What actually happened was that Christian personal names, first and foremost saints' names and some names from the New Testament, gradually came into use in the course of the twelfth century, and by the thirteenth century these names had become more popular than the old Scandinavian personal names. There is nothing to suggest, however, that it was the names with cultic elements that were the most liable to drop out of favour.

This development in the nomenclature did not take place suddenly but over a comparatively long period of time. In the so-called Broderliste (List of brothers) from the end of the twelfth century, which is recorded in King Valdemar's cadastre, only about $23 \%$ of the men named bear Christian names, while about $75 \%$ have Scandinavian names. At least 40 of the men, all of whom belonged to the most distinguished aristocratic families in Denmark, bore names containing pre-Christian cultic elements.

There is nothing to suggest an organized attempt on the part of the church to change the Danish personal nomenclature. A more militant and aggressive Christianity would have gone into action on this point. 
From later periods we are familiar with the way in which civil authorities have infringed the rights of religious and political minorities to choose their names freely. There was, for example, the regulation and germanization of Jewish nomenclature in Austria and Germany by decrees issued at the end of the eighteenth century. Surnames such as Morgenschweiss, Axelgeruch, Silbertau, Rubinstein, Stiefelschaft, forced upon Jewish families instead of their original Jewish names, are a symbol of the invidious attitude taken by the authorities to this ethnic group. It might also be mentioned that the Turkish minority in present-day Bulgaria has been obliged to adopt Bulgarian names. No such interference with the nomenclature seems to have followed in the wake of Christianity in our part of the world.

Let us turn now to the place-names. What happened to these in the missionary period? When the new religion arrived in Denmark, it was confronted not only by the cultic sites of the old religion but also by the names of these sites. Many of these names must have described the cultic function of the localities denoted. It was of course within the power of the victorious church to destroy the old cultic sites and temples and perhaps to establish its own holy-places in the same locations. What happened to the names, however? Were they also obliterated and replaced by new names? And what happened to the names of such natural features: groves, fields, springs etc. as were the objects of, or sites for, cultic activities? Were their names also eradicated if they described the locality in question as being holy? Can the answer to these questions reveal anything about the nature of the mission?

Let us begin by noting that a comparatively large number of names with a cultic, pre-Christian content has survived until the present day. These are mainly names which refer to the object of the cult, i.e. the gods (typical example: Odins-vi > Odense), to the site of the cult (typical example: Vi-bjerg $>$ Viborg) and to concepts connected with the cult, its holiness (typical example: Hellignæs > Helgenæes, Helnas). Surviving pre-Christian place-names referring to the performers of the cultic activities, i.e. the heathen priesthood, to cultic accessories, i.e. furniture, appliances etc., and to the practice of the cult, i.e. sacrifices, invocations etc., are, on the other hand, few and far between and some of the instances are doubtful (Dalberg \& Kousgård Sørensen 1979, $119 \mathrm{ff}$.). Place-names form a body of source material to which much attention was paid in earlier times but which has only now been brought into focus again after half a century during which 
the information it could be made to yield has been regarded with a sterile scepticism.

The immediate conclusion to be drawn from the fact that relatively many cultic, pre-Christian place-names survive to the present day is that they can hardly have been felt to be particularly offensive by the devotees of the new religion. Or to express this in a different way, the church elected to act with circumspection. Christianity was not to be imposed upon the Danish population with such speed or fanatiscism or force that every trace of the old religion was to be obliterated. Perhaps it would simply have been impossible to do this.

This answer is probably, however, too simple. Allow me to point to some factors which need to be taken into consideration before a more balanced assessment can be made of the evidence provided by place-names as to the progress of the conversion.

Firstly, my earlier immediate conclusion was based on the positive evidence, that is the survival of comparatively many cultic placenames. Strictly speaking, however, there is no way of knowing how many more names were replaced in the missionary period by names more congenial to the church. We only have documentary evidence for a very few changes of name in the medieval period (Lisse 1974, 118). Among the instances where we have information as to both the replaced and the replacing name, there is not a single case of replacement of a pre-Christian cultic name. This is not really surprising, for a couple of centuries passed by between the conversion and the compilation of the earliest full records to survive. The possibility cannot be excluded, however, that our surviving pre-Christian cultic names are only the remnants of a much more extensive network of names related to the cult which were not viewed with favour by the church.

Furthermore, it must be remembered that the energy and enthusiasm with which a hypothetical campaign for the eradication of heathen names was carried out may have varied greatly from place to place. Let me mention an example. It has been the cause of some surprise that the island of Falster, whose place-names are among those in Denmark which have been subjected to the most intensive examination, has not yielded a single instance of a place-name with certain pre-Christian cultic content. This does not of course mean that the old heathen gods were not worshipped on the island. On the contrary, there are two parish-villages called Kirkeby (Nørre-, Sønder-), one in each of the two administrative herreds (hundreds) into which the island is divided. In spite of their overtly Christian names, these villages must 
themselves date back to before the introduction of Christianity. They must therefore have had other names before the present ones, which are, however, the only ones of which there is any record. There is also the peculiar fact that Nørre Kirkeby and Sønder Kirkeby, which have central positions in their individual herreds and which are not adjoining, are named jointly (utrumqve Kyrkybu) in the so-called Kongelevsliste (List of Crown lands) in King Valdemar's cadastre. Apart from the woodland on the Farnæs peninsula, the two Kirkebys are the only Crown lands on the island and the Crown lands recorded in early sources have been assumed to consist largely of property confiscated from heathen temples (Hald 1963, $108 \mathrm{f}$.). It has therefore been suggested that the two Kirkebys in Falster are old pre-Christian cult-places whose names were replaced by their present ones in the first phase of Christianization. It has also been suggested that they may have been called Viby but this is only one possibility among many. "Perhaps the struggle between paganism and Christianity was bitter just here so that men wished to remove all trace of paganism and, as a gesture of defiance, established the first churches in the old Vibys". Thus wrote Marius Kristensen (Kristensen 1921, $30 \mathrm{f}$;; cf. also Lisse 1974, 122 f.). He added that the only known runic-stone from Falster has an inscription which ends with an invocation to Tor to consecrate the runes. The stone stood in Sønder Kirkeby until it was removed to the National Museum in Copenhagen.

A third factor is concerned with the surviving pre-Christian cultic names. Their survival is not necessarily the reflection of a tolerant mission. It is conceivable that it was only those cultic names which were lexically transparent at the period of the conversion which were liable to be replaced. More archaic cultic elements, which were no longer recognised as such, would be left alone. If nobody understood the cultic content of the place-names, then nobody would feel the need to reject them. I should like to draw attention to a group of names which may not have been understood as pre-Christian cultic names. In Denmark there are a handful of names containing the name of the god Njord, which takes the form Nær (Nærä, Ncrum etc.). As far as I can see, there is no reason to believe that this god was worshipped in the last centuries of heathendom. The name of the god was unfamiliar to the local population as well as to the missionaries, and place-names in $N \propto r$ - could no longer be analyzed correctly. They would have been treated as lexically opaque labels for localities, as were so many other names, and consequently left untouched.

Other items from the old cultic onomasticon were immediately ac- 
ceptable because they could simply be treated as though they denoted Christian concepts. The fact that the word gud 'god' occurs in many pre-Christian place-names in Denmark, Guth-hem alone makes five appearances (Kousgård Sørensen 1985, $131 \mathrm{ff}$.), would not have troubled the missionaries because this was the very word they used of the divinity they worshipped. One of the words to express the cultic concept in the Germanic languages was hellig and this was used not only by the pre-Christian religion, but also by Christianity, so that the heathen Hellig-names in Denmark, e.g. Helnces, Helgences, could be transferred without difficulty into the Christian universe.

It is thus not possible to state unreservedly that the relatively numerous cultic place-names which survived the conversion show that Christianization had taken place gradually and peacefully. We have no way of knowing how many names were actually understood by the mission as being pre-Christian cultic names and hence rejected and replaced by more acceptable names. Some names were not understood to be cultic names and were therefore without interest in this context, while other names could simply be used as "Christian" names. Finally, account must be taken of the fact that the clash between the two religions was more violent in some localities than in others and that where the clash was most violent, the consequences for the heathen nomenclature would probably have been most severe.

Nevertheless, there do indeed survive comparatively many names which must have been understood in the tenth century both by the missionaries and by the local population as containing reminiscences of the old religion. The name Odins-vi is borne by at least four different localities in Denmark and the meaning of its component elements must have been clear to everyone in the missionary period. The fact that the third largest city in Denmark is one of the bearers of this name and to this very day is known as Odense shows that some at least of the missionaries were wise enough to realise that it was more important to preach the new religion than to eradicate symbols of the old one, whether these took the form of place-names or, as we noted earlier, personal names.

How were heathen names treated outside Scandinavia? Our knowledge of the reception given to the pre-Christian cultic place-nomenclature by the Christian church in southern and western Europe is restricted. This may be in part because any name-changes which may have taken place in connection with the conversion were effected long before there was a tradition for recording names in written sources so that it is extremely rare for both the old and the new names of a 
locality to be known.

Permit me, however, to quote a few examples to show that the old names were not automatically permitted to survive. The highest point in Paris was known in the pre-Christian period as the Hill of Mercury, Mons Mercuri. Evidence of the worship of this Roman god here was removed in the early Christian period and in the ninth century a sanctuary was built here, dedicated to the 10000 martyrs. The hill was then called Mons Martyrum, the name by which it is still known (Mont Martres) (Longnon 1923, 377; Vincent 1937, 307). San Marino in northern Italy, the shrine of Saint Marino, replaced a pre-Christian cultic name for the place: Monte Titano, where the Titans had been worshipped (Pfeiffer 1980, 79). ${ }^{1}$ A Monte Giove "Hill of Jupiter" came to be known as San Bernardo, in honour of St Bernhard (Pfeiffer 1980, 79). ${ }^{2}$ In Germany an old Wodanesberg "Hill of Odin" was renamed Godesberg (Bach 1956, 553). A controversial but not unreasonable suggestion is that the locality named by Adam of Bremen as Fosetisland "land of the god Foseti" is to be identified with Helgoland "the holy land", the island off the coast of northern Friesland which, according to Adam, was treated with superstitious respect by all sailors, particularly pirates (Laur 1960, 360 with references).

The irregular geographical distribution of surviving pagan placenames in England may, according to Margaret Gelling (Gelling 1961, 20; Gelling 1973, 117), indicate that Christianity during the conversion period was unable to bring its influence to bear in areas which were at some distance from the centres of missionary activity. Consequently, neither institutions nor names were replaced in these areas. Margaret Gelling has also drawn attention to Bede's description of the acceptance of Christianity by the Northumbrian court. "The story ends with the high priest mounting a stallion and riding out to destroy his temple. This was presumably his main temple, and here if anywhere one might have expected a place-name such as Wyham or Harrow; but, says Bede, "today it is called Goodmanham" (Gelling 1973, 118). There are more examples of such renaming from Southern and Western Europe but they are not very numerous.

It is not easy to demonstrate interference with the nomenclature on the part of the new religion but it is less difficult to trace the effect on names of political upheavals, since these have generally taken place in

1 Cited after Olivieri, D. 1965. Dizionario di Toponomastica Piemontese. Brescia.

2 Cited after Pollini, A. 1965. Toponomastica Romagnola. Firenze. 
periods for which the documentary evidence is more abundant. Since conversion and revolution both involve clashes of ideology, it may be justified to add a few comments on the latter phenomenon. I shall be brief, since the subject has recently been well treated by Sven Benson in an article dealing with various forms of change of placename (Benson 1986, $96 \mathrm{ff}$.).

From our own part of the world we may recall that the old name of the capital of Norway, Oslo, was replaced in the middle of the 1620s by Kristiania, not so much out of dislike of the old name as to honour the king, Christian IV, but that the city was given its old name again in 1925, on the grounds that the name of a Danish king was not a suitable element to be present in the name of the capital of Norway.

We are all familiar with examples of politically motivated re-naming in the twentieth-century. St Petersburg, later Petrograd, was renamed Leningrad in 1924. Königsberg was renamed Kaliningrad. Stalingrad is now known as Volgograd, etc. The former colonial areas in, for example, Africa have taken the same line: Léopoldville is now known as Kinshasa, Northern Rhodesia as Zambia, Southern Rhodesia as Zimbabwe.

The political motivation behind such place-name changes, which are legion, can normally be identified. Similar situations were also presumably likely to arise in times of religious unrest and upheaval. The further back we go in time, however, the sparser the documentation and this makes an assessment of the situation more difficult. In theory, and in practice, only one of the two ideologically loaded names would survive, while the other name, the one which was to be replaced, would be superseded and, after a couple of generations, not just forgotten locally but also, at a period without an established tradition of writing, lost to posterity.

With these last remarks I have simply wanted to warn against adopting a too simplistic view of the process of the Christianization of Denmark. The fate of the nomenclature in the period does suggest that the change in religion took place reasonably peacefully and gradually. There are, however, certain features about the place-names suggesting that there were local differences in the conduct of the mission. We do not in fact know how many of the pre-Christian cultic place-names were allowed to survive. What we know about parallel situations out in the wide world might reasonably give us food for thought. 


\section{Bibliography}

Bach, A. 1956. Deutsche Namenkunde 2, 2. Heidelberg.

Benson, S. 1986. Ortsnamenwechsel. Beiträge zur Namensforschung N.F., Beiheft 24. Heidelberg.

Dalberg, V. \& Kousgård Sørensen, J. 1979. Stednavneforskning 2. København.

Gelling, M. 1961. Place-names and Anglo-Saxon paganism. Historical Journal 8, 1. Cambridge.

- 1973. Further thoughts on pagan place-names. Otium et Negotium. Stockholm.

Hald, K. 1963. The cult of Odin in Danish place-names. Early English and Norse studies presented to Hugh Smith. Ed. by A. Brown \& P. Foote. London.

Kousgård Sørensen, J. 1974. Odinkar og andre navn på -kar. Nordiska namn. Namn och bygd 62 . Uppsala.

- 1985. Gudhem. Frühmittelalterliche Studien 19. Berlin.

Kristensen, M. 1921. Lålands og Falsters stednavne. Lolland-Falsters historiske Samfunds Aarbog. Nykøbing Falster.

Laur, W. 1960. Die Ortsnamen in Schleswig-Holstein. Schleswig.

Lisse, C. 1974. "Gøkstorp qvod nunc Knutstorp dicitur". Festskrift til Kristian Hald. (Navnestudier 13.) København.

Longnon, A. 1923. Les noms de lieu de la France. Paris.

Pfeiffer, G. 1980. Kirche und Ortsnamengebung. Beiträge zur Namenforschung N.F., Beiheft 18. Heidelberg.

Sawyer, B. 1987. Scandinavian conversion histories. The Christianization of Scandinavia. Ed. by B. Sawyer \& P. Sawyer \& I. Wood. Alingsås.

Vincent, A. 1937. Toponymie de la France. Bruxelles. 